\title{
Arylpalladium Phosphonate Complexes as Reactive Intermediates in Phosphorus-Carbon Bond Forming Reactions
}

\author{
Mark C. Kohler, ${ }^{\dagger}$ Thomas V. Grimes, ${ }^{\#}$ Xiaoping Wang, ${ }^{\star}$ Thomas R. Cundari, ${ }^{*}, *$ and \\ Robert A. Stockland, Jr. ${ }^{*}$, \\ Department of Chemistry, Bucknell University, Lewisburg, Pennsylvania 17837, and Department of \\ Chemistry, Center for Advanced Scientific Computing and Modeling (CASCaM), University of North \\ Texas, Denton, Texas 76203
}

Received September 17, 2008

\begin{abstract}
Phosphorus - carbon bond formation from discrete transition metal complexes have been investigated through a combination of synthetic, spectroscopic, crystallographic, and computational methods. Reactive intermediates of the type (diphosphine) $\mathrm{Pd}(\operatorname{aryl})\left(\mathrm{P}(\mathrm{O})(\mathrm{OEt})_{2}\right)$ have been prepared, characterized, and studied as possible intermediates in metal-mediated coupling reactions. Several of the reactive intermediates were characterized crystallographically, and a discussion of the solid state structures is presented. In contrast to other carbon-heteroelement bond forming reactions, palladium complexes containing electrondonating substituents on the aromatic fragment exhibited faster rates of reductive elimination. Large bite angle diphosphine ligands induced rapid rates of elimination, while bipyridine and small bite angle diphosphine ligands resulted in much slower rates of elimination. An investigation of the effect of typical impurities on the elimination reaction was carried out. While excess diphosphine, pyridine, and acetonitrile had little effect on the observed rate, the addition of water slowed the phosphorus-carbon bond forming reaction. Coordination of water to the complex was observed spectroscopically and crystallographically. Computational studies were utilized to probe the reaction pathways for $\mathrm{P}-\mathrm{C}$ bond formation via $\mathrm{Pd}$ catalysis.
\end{abstract}

\section{Introduction}

Carbon-heteroelement bond forming reactions are critical transformations used to construct a range of organic architectures. For the formation of phosphorus-carbon bonds, Arbuzov and related reactions are some of the most popular approaches and are used to generate alkylphosphonates in high yields. ${ }^{1}$ However, aryl halides are typically unreactive under Arbuzov conditions. To resolve this issue, nickel- ${ }^{2}$ copper- ${ }^{3,4}$ and palladium-catalyzed ${ }^{5-9}$ coupling reactions of hydrogen phosphonates and other $\mathrm{R}_{2} \mathrm{P}(\mathrm{O}) \mathrm{H}$ substrates with aryl halides have been developed. ${ }^{10}$ Despite the harsh conditions of these reactions, the transformations have become powerful assets to the synthetic chemist due to high conversions and minimization of unwanted secondary processes. To develop highly active catalysts for this reaction, an understanding of the electronic

\footnotetext{
* Corresponding author. E-mail: rstockla@bucknell.edu.

${ }^{*}$ Current address: Fukui Institute for Fundamental Chemistry, Kyoto University, Kyoto 606-8103, Japan.

† Bucknell University.

$¥$ University of North Texas.

(1) Bhattacharya, A. K.; Thyagarajan, G. Chem. Rev. 1981, 81, 415.

(2) Yao, Q.; Levchik, S. Tetrahedron Lett. 2006, 47, 277.

(3) Huang, C.; Tang, X.; Fu, H.; Jiang, Y.; Zhao, Y. J. Org. Chem. 2006, 71,5020 .

(4) Thielges, S.; Bisseret, P.; Eustache, J. Org. Lett. 2005, 7, 681

(5) Schwan, A. L. Chem. Soc. Rev. 2004, 33, 218.

(6) Kwong, F. Y.; Chan, K. S. Organometallics 2000, 19, 2058.

(7) Kwong, F. Y.; Lai, C. W.; Tian, Y.; Chan, K. S. Tetrahedron Lett. 2000, 41, 10285 .

(8) Martorell, G.; Garcias, X.; Janura, M.; Saa, J. M. J. Org. Chem. 1998, 63, 3463.

(9) Moncarz, J. R.; Brunker, T. J.; Glueck, D. S.; Sommer, R. D.; Rheingold, A. L. J. Am. Chem. Soc. 2003, 125, 1180.

(10) Beletskaya, I. P.; Kazankova, M. A. Russ. J. Org. Chem. 2002, 38,1391 .
}

and steric effects of the organic fragments on the individual steps of the transformation is needed.

We and others have been interested in elucidating the key mechanistic steps in palladium-catalyzed $\mathrm{P}-\mathrm{C}$ bond forming reactions. ${ }^{11-39}$ To this end, we recently studied arylphosphonate

(11) (a) Kohler, M. C.; Stockland, R. A., Jr.; Rath, N. P. Organometallics 2006, 25, 5746. (b) Stockland, R. A., Jr.; Wilson, B. D.; Goodman, C. C.; Giese, B. J.; Shrimp, F. L., II. J. Chem. Ed. 2007, 84, 694.

(12) (a) Levine, A. M.; Stockland, R. A., Jr.; Clark, R.; Guzei, I. Organometallics 2002, 21, 3278. (b) Ide, D. M.; Eastlund, M. P.; Jupe, C. L.; Stockland, R. A., Jr. Curr. Org. Chem. 2008, 12, 1258. (c) Kalek, M.; Stawinski, J. Organometallics 2007, 26, 5840. (d) Kalek, M.; Stawinski, J. Organometallics 2008, 27, 5876. (e) Blank, N. F.; Moncarz, J. R.; Brunker, T. J.; Scriban, C.; Anderson, B. J.; Amir, O.; Glueck, D. S.; Zakharov, L. N.; Golen, J. A.; Incarvito, C. D.; Rheingold, A. L. J. Am. Chem. Soc. 2007, 129, 6847. (f) Moncarz, J. R.; Brunker, T. J.; Jewett, J. C.; Orchowski, M.; Glueck, D. S.; Sommer, R. D.; Lam, K.-C.; Incarvito, C. D.; Concolino, T. E.; Ceccarelli, C.; Zakharov, L. N.; Rheingold, A. L. Organometallics 2003, 22, 3205.

(13) Stockland, R. A., Jr.; Levine, A. M.; Giovine, M. T.; Guzei, I. A.; Cannistra, J. C. Organometallics 2004, 23, 647.

(14) Han, L. B.; Choi, N.; Tanaka, M. Organometallics 1996, 15, 3259.

(15) Han, L. B.; Hua, R. M.; Tanaka, M. Angew. Chem., Int. Ed. 1998, $37,94$.

(16) Han, L. B.; Mirzaei, F.; Zhao, C. Q.; Tanaka, M. J. Am. Chem. Soc. 2000, 122, 5407.

(17) Han, L. B.; Tanaka, M. J. Am. Chem. Soc. 1996, 118, 1571.

(18) Han, L. B.; Zhao, C. Q.; Onozawa, S. Y.; Goto, M.; Tanaka, M. J. Am. Chem. Soc. 2002, 124, 3842 .

(19) Allen, A.; Ma, L.; Lin, W. B. Tetrahedron Lett. 2002, 43, 3707.

(20) Allen, A.; Manke, D. R.; Lin, W. B. Tetrahedron Lett. 2000, 41, 151.

(21) Alonso, F.; Beletskaya, I. P.; Yus, M. Chem. Rev. 2004, 104, 3079.

(22) Baillie, C.; Xiao, J. L. Curr. Org. Chem. 2003, 7, 477.

(23) Beletskaya, I. P.; Afanasiev, V. V.; Kazankova, M. A.; Efimova, I. V. Org. Lett. 2003, 5, 4309.

(24) Clarke, M. L.; Orpen, A. G.; Pringle, P. G.; Turley, E. Dalton Trans. 2003, 4393.

(25) Deprele, S.; Montchamp, J. L. J. Am. Chem. Soc. 2002, 124, 9386. 
formation from discrete reaction intermediates of the type $\mathrm{bu}_{2}$ bipyPd( $\left.\mathrm{Ar}\right)\left(\mathrm{P}(\mathrm{O})(\mathrm{OR})_{2}\right)$ (eq 1). ${ }^{11}$ These complexes represented the first examples of isolated four-coordinate arylpalladium complexes containing a phosphonate fragment and were quite resistant to reductive elimination at $25^{\circ} \mathrm{C}$. An investigation of the conditions necessary to induce reductive elimination from these intermediates would provide insight into the key phosphorus - carbon bond forming step in palladium-catalyzed arylphosphonate synthesis. Furthermore, the chelating ligand forced the aryl and phosphonate fragments to be bound to the metal center in a cis fashion; thus, isomerization was not a prerequisite for reductive elimination from these compounds. The arylpalladium phosphonate compounds were quite stable at $25{ }^{\circ} \mathrm{C}$ in the solid state and in solution. However, all examples underwent clean reductive elimination in $\mathrm{C}_{6} \mathrm{D}_{6}$ solutions at elevated temperatures in sealed tubes $\left(90-120^{\circ} \mathrm{C}\right)$. In contrast with other carbon-heteroelement bond forming reactions from $\mathrm{Pd}(\mathrm{II}),{ }^{40}$ metal-bound aryl fragments bearing electron-donating groups accelerated the elimination process, while $-\mathrm{NO}_{2},-\mathrm{Cl}$, or $-\mathrm{CN}$ groups resulted in sluggish phosphorus-carbon bond formation. Although the use of bipyridine-based ligands facilitated the isolation and characterization of these potential intermediates, most palladium-catalyzed coupling reactions involve monodentate or bidentate phosphine donors. The efficacy of diphosphine ligands for promoting the formation of phosphorus-carbon bonds by reductive elimination from discrete reaction intermediates of the type (diphosphine)Pd(Ar)$\left(\mathrm{P}(\mathrm{O})(\mathrm{OR})_{2}\right)$ would be of interest for the design and development of more efficient catalysts.

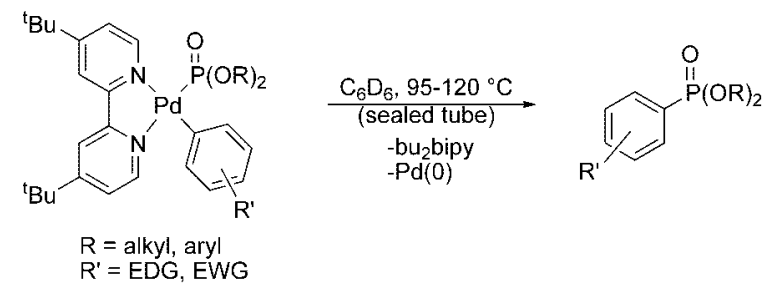

\section{Results and Discussion}

Synthesis of Organopalladium Precursors. We have recently reported that silver phosphonates are convenient precur-

(26) Gulykina, N. S.; Dolgina, T. M.; Bondarenko, G. N.; Beletskaya, I. P. Russ. J. Org. Chem. 2003, 39, 797.

(27) Gulyukia, N. S.; Dolgina, T. M.; Bondarenko, G. N.; Beletskaya, I. P.; Bondarenko, N. A.; Henry, J. C.; Lavergne, D.; RatovelomananaVidal, V.; Genet, J. P. Russ. J. Org. Chem. 2002, 38, 573.

(28) Leoni, P.; Vichi, E.; Lencioni, S.; Pasquali, M.; Chiarentin, E.; Albinato, A. Organometallics 2000, 19, 3062.

(29) Mirzaei, F.; Han, L. B.; Tanaka, M. Tetrahedron Lett. 2001, 42 297.

(30) Shulyupin, M. O.; Kazankova, M. A.; Beletskaya, I. P. Org. Lett. 2002, 4, 761 .

(31) Tanaka, M. In Homogeneous Catalysis for H-P Bond Addition Reactions; New Aspects in Phosphorus Chemistry; 2004; Vol. 232, p 25.

(32) Trzeciak, A. M.; Ziolkowski, J. J. Pol. J. Chem. 2003, 77, 749.

(33) Zhao, C. Q.; Han, L. B.; Tanaka, M. Organometallics 2000, 19, 4196.

(34) Belabassi, Y.; Alzghari, S.; Montchamp, J. J. Organomet. Chem. 2008, 693, 3171

(35) Bravo-Altamirano, K.; Huang, Z.; Montchamp, J. Tetrahedron 2005, 61,6315 .

(36) Dobashi, N.; Fuse, K.; Hoshino, T.; Kanada, J.; Kashiwabara, T.; Kobata, C.; Nune, S. K.; Tanaka, M. Tetrahedron Lett. 2007, 48, 4669.

(37) Dumond, Y. R.; Montchamp, J. J. Organomet. Chem. 2002, 653 252.

(38) Han, L. B.; Ono, Y.; Shimada, S. J. Am. Chem. Soc. 2008, 130, 2752.

(39) Holt, D. A.; Erb, J. M. Tetrahedron Lett. 1989, 30, 5393.

(40) Hartwig, J. F. Inorg. Chem. 2007, 46, 1936.
Table 1. Arylpalladium Phosphonate Precursors

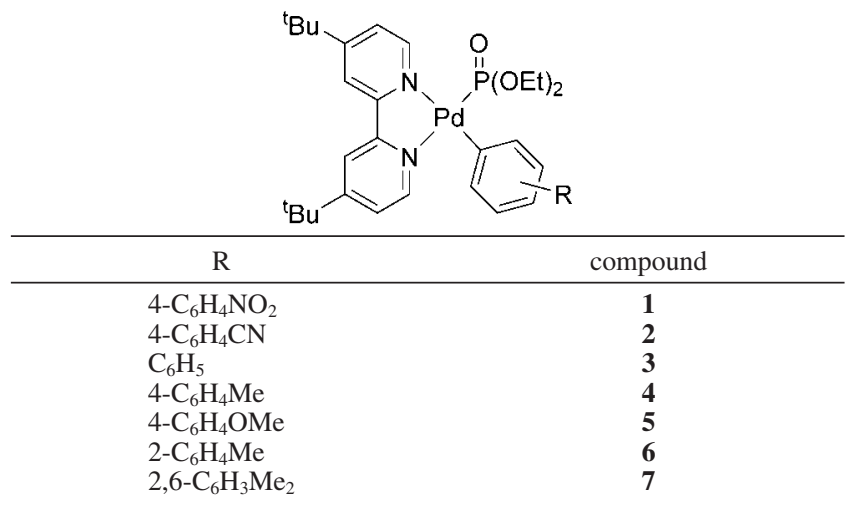

sors to palladium and gold phosphonate species. ${ }^{11,12 \mathrm{a}, 13}$ For example, treatment of $\left(\mathrm{bu}_{2}\right.$ bipy) $\mathrm{Pd}(\mathrm{R}) \mathrm{Cl}$ with 1.0 equiv of $\mathrm{Ag}\left[\mathrm{P}(\mathrm{O})(\mathrm{OR})_{2}\right]$ generated $\left(\mathrm{bu}_{2}\right.$ bipy $) \mathrm{Pd}(\mathrm{R})\left(\mathrm{P}(\mathrm{O})(\mathrm{OR})_{2}\right)$ compounds in high yields. Simple filtration and removal of the volatiles typically afforded high yields of the desired complexes. For this work, diphosphine-ligated compounds were the synthetic targets, and it seemed appropriate that treatment of (diphosphine) $\mathrm{Pd}(\mathrm{R}) \mathrm{Cl}$ species with the silver phosphonate salts should result in the formation of the desired compounds. However, extensive experimentation yielded only decomposition and the formation of palladium mirrors. Thus an alternate method for the generation of the diphosphinePd(R) $\left(\mathrm{P}(\mathrm{O})(\mathrm{OR})_{2}\right)$ species was needed. Since diphosphines are typically stronger donors for palladium than bipyridines, addition of diphosphine to a solution of the $\mathrm{bu}_{2}$ bipyPd( $\left.\mathrm{Ar}\right)\left(\mathrm{P}(\mathrm{O})(\mathrm{OR})_{2}\right)$ species could result in displacement of the bipyridine ligand and result in the formation of the desired complexes. Using bu $\mathrm{b}_{2} \mathrm{bipyPd}(\mathrm{Ph})-$ $\left(\mathrm{P}(\mathrm{O})(\mathrm{OEt})_{2}\right)$ as a model system, addition of 1.0 equiv of dppe (in $\mathrm{C}_{6} \mathrm{D}_{6}$ solution) resulted in immediate and quantitative elimination of the bipyridine and generation of $\operatorname{dppePd}(\mathrm{Ph})$ $\left(\mathrm{P}(\mathrm{O})(\mathrm{OEt})_{2}\right)$. Additionally, analysis of the ${ }^{1} \mathrm{H}$ NMR spectrum of this reaction mixture within a few minutes of diphosphine addition revealed the presence of $\mathrm{PhP}(\mathrm{O})(\mathrm{OEt})_{2}$. This suggested that elimination from the diphosphine-ligated compounds will occur at significantly reduced temperatures as compared to the bipyridine species.

With the development of a successful system for the preparation of the desired intermediates, a series of compounds were prepared using a range of arylpalladium precursors (Table 1) to provide a comparison of the electronic and steric effects of the metal-bound aryl fragment. The diphosphines, dppe, dppp, and dpephos, were selected and $-\mathrm{P}(\mathrm{O})(\mathrm{OEt})_{2}$ was chosen as the prototypical phosphonate fragment due to its rich history in the synthesis of organic compounds. ${ }^{41}$ Using dppe as the diphosphine, treatment of $\mathrm{C}_{6} \mathrm{D}_{6}$ solutions of $\mathbf{1 - 7}$ with dppe generated the arylpalladium phosphonate species by displacement of the $b_{2}$ bipy ligand. For $\mathbf{1 - 5}$, the displacement reaction was complete within a few minutes at $25^{\circ} \mathrm{C}$. For 6 and 7, the displacement reaction was slower, with the latter taking several hours to reach completion. Sharp resonances were observed for the free $\mathrm{bu}_{2}$ bipy ligand and bound diphosphine, suggesting that $\mathrm{bu}_{2}$ bipy does not compete with the diphosphine for the metal center. For $\mathbf{1 - 3}, \mathbf{6}$, and $\mathbf{7}$, the sluggish rate of reductive elimination from the diphosphine-ligated species facilitated isolation of these compounds. Monitoring the displacement reaction by NMR spectroscopy in tol- $d_{8}$ revealed that the

(41) dppe $=$ bis(diphenylphosphino)ethane, dppp = bis(diphenylphosphino)propane, dpephos = (oxydi-2,1-phenylene)bis(diphenylphosphine). 
displacement of $b_{2}$ bipy by dppe was quite rapid at $25^{\circ} \mathrm{C}$, but it was very slow at temperatures below $10^{\circ} \mathrm{C}$ and essentially nonexistent below $-10{ }^{\circ} \mathrm{C}$.

Changing the diphosphine to dppp resulted in similar results for most of the displacement reactions; however, elimination often occurred rapidly from the generated dpppPd $(\operatorname{Ar})(\mathrm{P}(\mathrm{O})(\mathrm{O}-$ $\mathrm{Et})_{2}$ ) compounds. This required the dppp ligated compounds to be generated and monitored in situ. For the precursors containing metal-bound aryl rings with electron-donating substituents, the rate of displacement was on the order of the reductive elimination, and the reactive intermediates were observed only at low temperature. For example, injecting $\mathrm{C}_{6} \mathrm{D}_{6}$ to the mixture of bu $_{2}$ bipyPd $\left(4-\mathrm{C}_{6} \mathrm{H}_{4} \mathrm{OMe}\right)\left(\mathrm{P}(\mathrm{O})(\mathrm{OEt})_{2}\right) /$ dppp followed by shaking for $5 \mathrm{~s}$ and flash freezing resulted in a mixture of unreacted starting materials $(40 \%)$, reactive intermediate $(5 \%)$, and products $\left(\left(4-\mathrm{C}_{6} \mathrm{H}_{4} \mathrm{OMe}\right) \mathrm{P}(\mathrm{O})(\mathrm{OEt})_{2} / \mathrm{dppp}_{2} \mathrm{Pd}(0), 55 \%\right)$. Similar to the reactions involving dppe, careful monitoring of this reaction by ${ }^{1} \mathrm{H}$ and ${ }^{31} \mathrm{P}\left\{{ }^{1} \mathrm{H}\right\}$ NMR spectroscopy using tol- $d_{8}$ as the solvent revealed that the effective temperature range for the displacement reaction was $15-25^{\circ} \mathrm{C}$. Only a trace amount of displacement/elimination was observed below $-10{ }^{\circ} \mathrm{C}$.

The final diphosphine studied in this investigation was dpephos. This diphosphine exhibits a large bite angle $\left(105^{\circ}\right)$ and has been used in a number of palladium-catalyzed reactions. ${ }^{42-45}$ Treatment of $\mathrm{C}_{6} \mathrm{D}_{6}$ solutions of $\mathbf{1 - 7}$ with this ligand resulted in immediate generation of the arylphosphonate ( $>97 \%$ by NMR). No intermediates were observed in the ${ }^{1} \mathrm{H}$ or ${ }^{31} \mathrm{P}\left\{{ }^{1} \mathrm{H}\right\}$ NMR spectrum of these reactions. To investigate this further, the displacement/elimination reaction was monitored by NMR spectroscopy at low temperatures using the model system of $\mathrm{bu}_{2}$ bipyPd $\left(4-\mathrm{C}_{6} \mathrm{H}_{4} \mathrm{CN}\right)\left(\mathrm{P}(\mathrm{O})(\mathrm{OEt})_{2}\right) / \mathrm{dpephos}$. This precursor was selected since the complexes incorporating electron-withdrawing groups on the metal-bound aryl exhibit the slowest rates of reductive elimination and would provide the best opportunity to observe the intermediate. At temperatures below $-20{ }^{\circ} \mathrm{C}$ (tol- $d_{8}$ ), sharp resonances for $\mathrm{bu}_{2}$ bipyPd(4$\left.\mathrm{C}_{6} \mathrm{H}_{4} \mathrm{CN}\right)\left(\mathrm{P}(\mathrm{O})(\mathrm{OEt})_{2}\right)$ and dpephos were observed in the ${ }^{31} \mathrm{P}\left\{{ }^{1} \mathrm{H}\right\}$ NMR spectrum. Warming this solution to $0{ }^{\circ} \mathrm{C}$ resulted in broadening of the signal for bu ${ }_{2}$ bipyPd $\left(4-\mathrm{C}_{6} \mathrm{H}_{4} \mathrm{CN}\right)$ $\left(\mathrm{P}(\mathrm{O})(\mathrm{OEt})_{2}\right)$ and the dpephos. Lowering the temperature to -50 ${ }^{\circ} \mathrm{C}$ resulted in regeneration of sharp signals for the arylpalladium complex and free dpephos. Warming this solution to a higher temperature $\left(10{ }^{\circ} \mathrm{C}\right)$ resulted in broadening of the signals for both bu bipyPd $_{2}\left(4-\mathrm{C}_{6} \mathrm{H}_{4} \mathrm{CN}\right)\left(\mathrm{P}(\mathrm{O})(\mathrm{OEt})_{2}\right)$ and dpephos along with generation of the arylphosphonate. No assignable signals for an intermediate of the type (dpephos) $\mathrm{Pd}\left(4-\mathrm{C}_{6} \mathrm{H}_{4} \mathrm{CN}\right)\left(\mathrm{P}(\mathrm{O})(\mathrm{OEt})_{2}\right)$ were observed. Allowing this solution to stand for a few seconds at $25{ }^{\circ} \mathrm{C}$ and flash freezing in liquid nitrogen followed by observation at $-50{ }^{\circ} \mathrm{C}$ also did not reveal an intermediate. In contrast to all of the reactions involving dppe, where displacement of the bipyridine ligand was relatively rapid compared to elimination, the rate of elimination is faster than the displacement reaction and no intermediates were observed. This could be due to complete displacement of the bu $\mathrm{bu}_{2}$ bipy ligand and formation of a four-coordinate dpephosPd(4- $\left.\mathrm{C}_{6} \mathrm{H}_{4} \mathrm{CN}\right)$ $\left(\mathrm{P}(\mathrm{O})(\mathrm{OEt})_{2}\right)$ that simply has a very fast rate of reductive elimination due to the large bite angle or rapid dissociation of one end of the dpephos to generate a three-coordinate palladium

(42) Shi, J. C.; Zeng, X.; Negishi, E. I. Org. Lett. 2003, 5, 1825.

(43) Qian, M.; Huang, Z.; Negishi, E. I. Org. Lett. 2004, 6, 1531

(44) van Leeuwen, P. W. N. M.; Zuideveld, M. A.; Swennenhuis, B. H. G.; Freixa, Z.; Kamer, P. C. J.; Goubitz, K.; Fraanje, J.; Lutz, M.; Spek, A. L. J. Am. Chem. Soc. 2003, 125, 5523.

(45) Yin, J.; Rainka, M. P.; Zhang, X. X.; Buchwald, S. L. J. Am. Chem. Soc. 2002, 124, 1162. complex. Alternatively, the elimination could be occurring from a mixed system where one end of the dpephos is attached to the palladium along with one end of the bipyridine ligand. The broadened signals in the ${ }^{31} \mathrm{P}\left\{{ }^{1} \mathrm{H}\right\}$ NMR spectrum for the free ligand and $\mathrm{bu}_{2}$ bipyPd $\left(4-\mathrm{C}_{6} \mathrm{H}_{4} \mathrm{CN}\right)\left(\mathrm{P}(\mathrm{O})(\mathrm{OEt})_{2}\right)$ at low temperatures suggested a dynamic process; however, the rapid arylphosphonate formation from the mixture precluded further investigation of the process.

For comparison studies, methylpalladium phosphonate complexes were prepared using similar procedures. Treatment of bu $_{2}$ bipyPdMeCl with 1 equiv of $\mathrm{Ag}\left[\mathrm{P}(\mathrm{O})(\mathrm{OEt})_{2}\right]$ in $\mathrm{CH}_{2} \mathrm{Cl}_{2}$ generated $\mathrm{bu}_{2}$ bipyPdMe $\left(\mathrm{P}(\mathrm{O})(\mathrm{OEt})_{2}\right)$ in high yield after filtration and removal of the volatiles. Treatment of this precursor with dppe and dppp rapidly generated the diphosphine $\mathrm{PdMe}(\mathrm{P}(\mathrm{O})(\mathrm{O}-$ $\mathrm{Et})_{2}$ ) species. In contrast to the arylpalladium phosphonate species, these alkyl analogues were quite stable, and no elimination was observed from the dppe analogue after standing at $22{ }^{\circ} \mathrm{C}$ for several months.

All of the observable intermediates exhibited static structures in solution with three resonances in the ${ }^{31} \mathrm{P}\left\{{ }^{1} \mathrm{H}\right\}$ NMR spectrum. The phosphonate group gave rise to a signal between 70.8 and $78.8 \mathrm{ppm}$, with the species containing the more electronreleasing metal-bound aryl groups giving rise to higher frequency chemical shifts. The trans ${ }^{2} J_{\mathrm{PP}}$ between the phosphonate and the phosphorus atom is significantly larger than the cis couplings and ranges between 551.4 and $589.9 \mathrm{~Hz}$. The two cis couplings ranged between 16.7 and $46.2 \mathrm{~Hz}$.

The solid state structures of several precursors and aryl palladium phosphonate species were studied by single-crystal $\mathrm{X}$-ray diffraction. The molecular structures are presented in Figure 1, and structural data are summarized in Table 3. Selected bond distances and angles are presented in Tables 4 and 5 . Single crystals of bu ${ }_{2}$ bipy $\mathrm{Pd}(\mathrm{Ph})\left(\mathrm{P}(\mathrm{O})(\mathrm{OEt})_{2}\right)$ and $\mathrm{bu}_{2}$ bipyPd(4$\left.\mathrm{C}_{6} \mathrm{H}_{4} \mathrm{NO}_{2}\right)\left(\mathrm{P}(\mathrm{O})(\mathrm{OEt})_{2}\right)$ were grown by slow diffusion of pentane into $\mathrm{CDCl}_{3}$ solutions of the complexes at $0{ }^{\circ} \mathrm{C}$. These compounds crystallize in the triclinic space group $P \overline{1}$ with two molecules per unit cell. The metal-carbon bond lengths of the two compounds are similar, and the palladium-nitrogen bonds are also similar despite being trans to different groups. Although many aspects of the structures are similar, the $\mathrm{P}-\mathrm{Pd}-\mathrm{C}$ and $\mathrm{P}-\mathrm{Pd}-\mathrm{N}$ (cis) angles differ by nearly $9^{\circ}$. Additionally, the $\mathrm{Pd}-$ $\mathrm{C}_{\text {ipso }}-\mathrm{C}_{\text {para }}$ angle deviates significantly from linearity in $\mathrm{bu}_{2}$ bipy$\mathrm{Pd}(\mathrm{Ph})\left(\mathrm{P}(\mathrm{O})(\mathrm{OEt})_{2}\right)\left(168.0^{\circ}\right)$ and bu $\mathrm{bu}_{2}$ bipyPd $\left(4-\mathrm{C}_{6} \mathrm{H}_{4} \mathrm{NO}_{2}\right)-$ $\left(\mathrm{P}(\mathrm{O})(\mathrm{OEt})_{2}\right)\left(172.5^{\circ}\right)$. In fact, analyzing the arylpalladium complexes in the Cambridge Structural Database ligated by dipyridyl- or ethylene-bridged diphospine ligands revealed that $\mathrm{bu}_{2}$ bipyPd $(\mathrm{Ph})\left(\mathrm{P}(\mathrm{O})(\mathrm{OEt})_{2}\right)$ has the largest deviation from linearity of any reported compound. Compounds dppePd(4$\left.\mathrm{C}_{6} \mathrm{H}_{4} \mathrm{CN}\right)\left(\mathrm{P}(\mathrm{O})(\mathrm{OEt})_{2}\right)$ and dppePdMe $\left(\mathrm{P}(\mathrm{O})(\mathrm{OEt})_{2}\right)$ crystallized in the orthorhombic and monoclinic space groups $P 2_{1} 2_{1} 2_{1}$ and $P 2{ }_{1} / c$, respectively. The palladium-carbon and palladiumphosphonate bonds are elongated in these complexes relative to the $b_{2}$ bipy-ligated compounds due to the greater trans influence of the phosphine donors, and the palladium-alkyl bond is slightly longer than the palladium-aryl bond. The $\mathrm{Pd}-\mathrm{C}_{\mathrm{ipso}}-\mathrm{C}_{\text {para }}$ angle in the arylpalladium complex is closer to linearity $\left(176.0^{\circ}\right)$ than in the related bipyridine palladium complexes. All of the crystals grown in this investigation contain a water molecule as a solvent of crystallization. In all structures the water is hydrogen bonded to the phosphoryl oxygen with oxygen-oxygen distances between 2.710(3) and 2.8078(15) $\AA$ and $\mathrm{O}-\mathrm{H}-\mathrm{O}$ angles between $162(3)^{\circ}$ and $175(2)^{\circ}$.

Reductive Elimination Studies. To investigate the electronic and steric effects of the metal-bound aryl fragment on reductive 

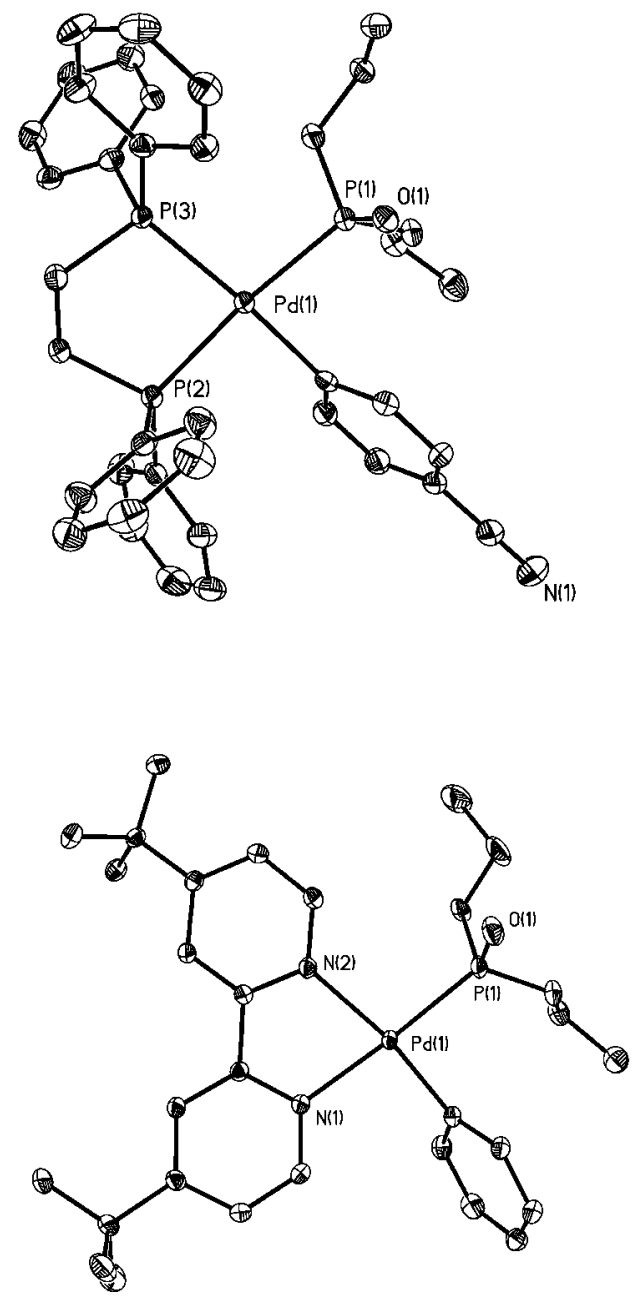
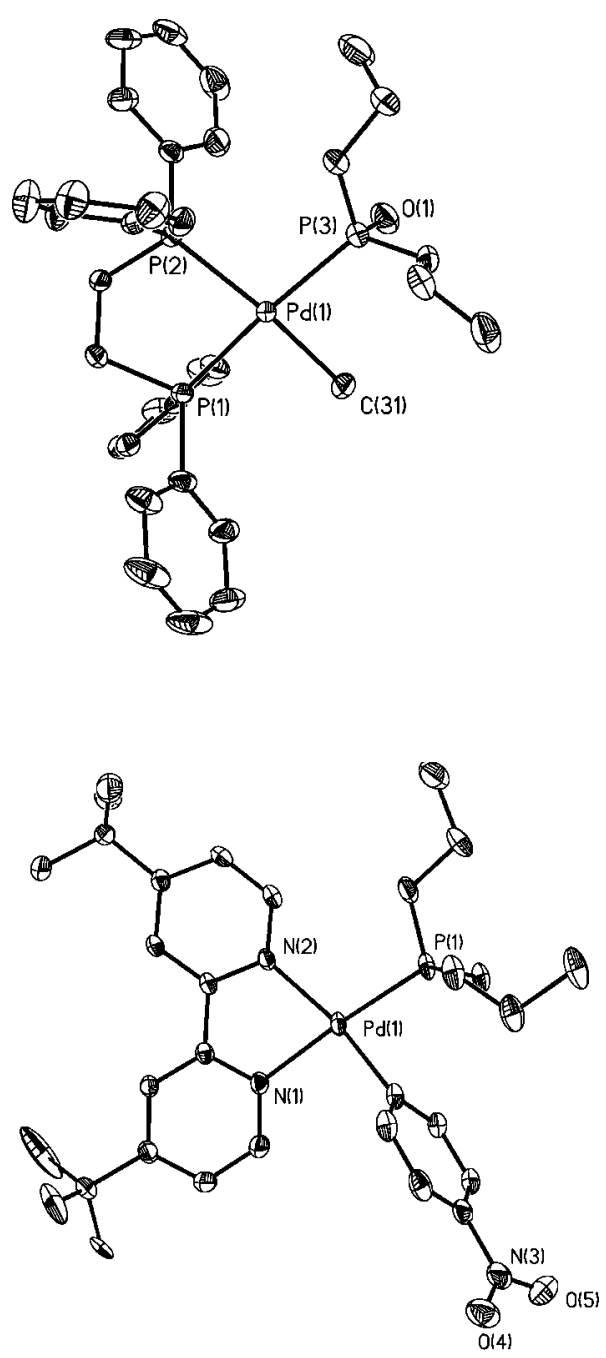

Figure 1. Molecular structures of dppePd $\left(\mathrm{C}_{6} \mathrm{H}_{4} \mathrm{CN}\right)\left(\mathrm{P}(\mathrm{O})(\mathrm{OEt})_{2}\right)$, dppePd $(\mathrm{Me})\left(\mathrm{P}(\mathrm{O})(\mathrm{OEt})_{2}\right)$, and bu $\mathrm{bipy} \mathrm{Pd}\left(4-\mathrm{C}_{6} \mathrm{H}_{4} \mathrm{R}\right)\left(\mathrm{P}(\mathrm{O})(\mathrm{OEt})_{2}\right)(\mathrm{R}=$ $\left.\mathrm{NO}_{2}, \mathrm{H}\right)$. Thermal ellipsoids are set at $50 \%$ probability.

elimination from these compounds, the phosphorus-carbon bond forming reaction was monitored using ${ }^{1} \mathrm{H}$ and ${ }^{31} \mathrm{P}\left\{{ }^{1} \mathrm{H}\right\}$ NMR spectroscopy. Solutions $\left(\mathrm{C}_{6} \mathrm{D}_{6}\right)$ of the intermediates were generated and held at $21.6^{\circ} \mathrm{C}$ for three half-lives, while NMR spectra were systematically collected. Comparison of the integral values for the intermediate complex and aryl phosphonate relative to an unreactive internal standard revealed the concentration of the intermediate and product. The reported kinetic data in the following tables represent the average of two independent experiments.

To provide a baseline for the elimination reactions, initial studies focused on the aryl palladium phosphonate complex containing the electron neutral $-\mathrm{C}_{6} \mathrm{H}_{5}$ group and dppe as the diphosphine. The results of the initial screening are summarized in Table 6. Generally, a dry NMR tube was charged with the arylpalladium phosphonate precursor, 2 equiv of dppe, (methoxymethyl)diphenylphosphine oxide (internal standard for both ${ }^{1} \mathrm{H}$ and ${ }^{31} \mathrm{P}$ NMR), and dry $\mathrm{C}_{6} \mathrm{D}_{6}$. NMR spectra were collected within minutes and revealed complete displacement of the $\mathrm{bu}_{2}$ bipy ligand and quantitative generation of the dppePdPh$\left(\mathrm{P}(\mathrm{O})(\mathrm{OEt})_{2}\right.$ as well as a small amount of arylphosphonate. Analysis of the integral data over three half-lives generated a linear first-order plot with $t_{1 / 2}=342 \mathrm{~min}$. The $t_{1 / 2}$ values for these elimination reactions were used to investigate the effect of different additives. At the end of the reaction, the only signals in the ${ }^{1} \mathrm{H}$ and ${ }^{31} \mathrm{P}$ NMR spectrum were due to $(\mathrm{dppe})_{2} \mathrm{Pd}(0)$,
$\mathrm{PhP}(\mathrm{O})(\mathrm{OEt})_{2}$, free $\mathrm{bu}_{2}$ bipy, and the internal standard. Comparison of the integral values for the starting complex and arylphosphonate revealed a greater than $95 \%$ conversion into $\mathrm{Ph}\left(\mathrm{P}(\mathrm{O})(\mathrm{OEt})_{2}\right)$. Analysis of the reaction mixture by $\mathrm{GC}$ and GCMS confirmed the lack of secondary products. Since the elimination was typically carried out in the presence of added diphosphine or $\mathrm{PPh}_{3}$ in order to trap the palladium(0) product formed in the reaction, elimination reactions were carried out using 5 and 10 equiv of diphosphine. Addition of excess diphosphine had a negligible effect on the rate of the elimination, suggesting the free phosphine simply traps the generated $\operatorname{Pd}(0)$. The reaction is also insensitive to 5 or 10 equiv of $b_{2}$ bipy. Ruling out involvement of the former in the rate of the reductive elimination reaction was critical since many of the arylpalladium phosphonate complexes eliminated rapidly upon formation and were generated in situ from the combination of 1-7 and diphosphine. Doubling the concentration of the arylpalladium phosphonate had no effect on the rate of the elimination process.

Since palladium-catalyzed arylphosphonate-forming reactions often employ hygroscopic hydrogen phosphonates, the effect of water on the reductive elimination was investigated. The addition of 1 equiv of water resulted in a negligible change in the rate of the elimination reaction. Notably, the complex was quite stable to the water, and $>95 \%$ conversion into $\mathrm{Ph}$ $\mathrm{P}(\mathrm{O})(\mathrm{OEt})_{2}$ was still observed. No hydrolysis products were observed in this reaction. Analysis of the ${ }^{1} \mathrm{H}$ NMR spectrum of 
Table 2. ${ }^{31} \mathbf{P}\left\{{ }^{1} \mathbf{H}\right\}$ NMR Data for the Reactive Intermediates

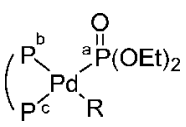

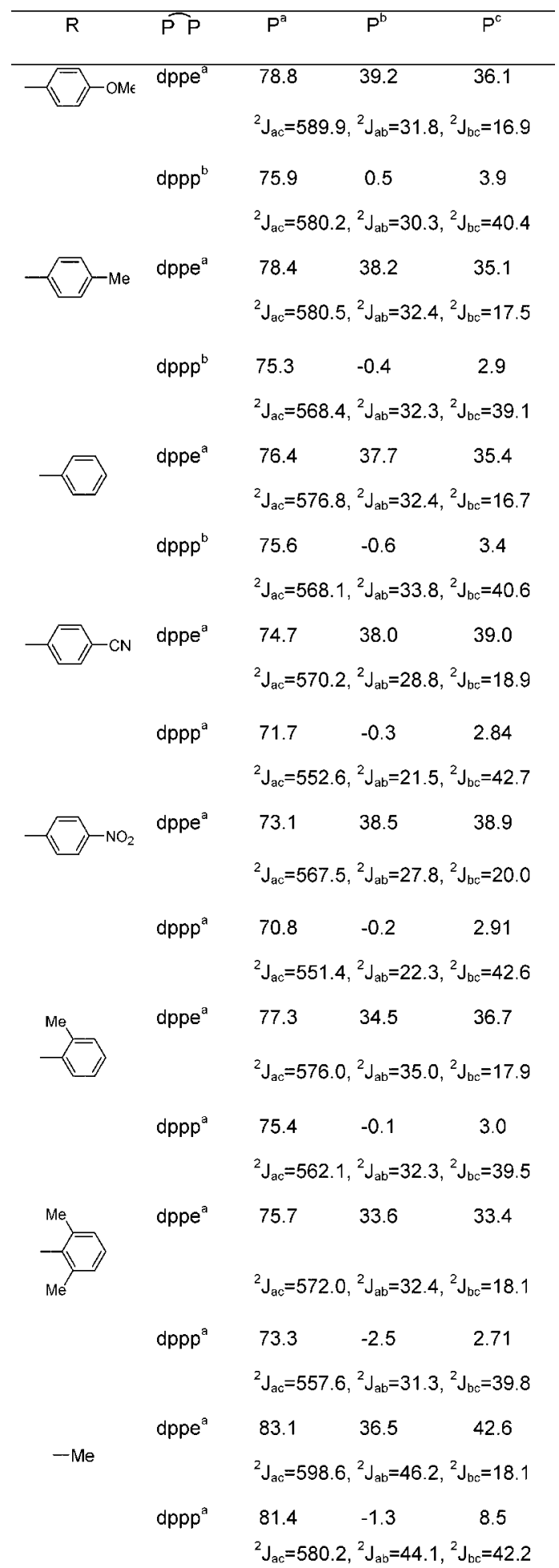
${ }^{\circ} \mathrm{C}$.

${ }^{a}$ Data recorded in $\mathrm{C}_{6} \mathrm{D}_{6}$ at $21.7{ }^{\circ} \mathrm{C} .{ }^{b}$ Data recorded in $\mathrm{C}_{6} \mathrm{D}_{6}$ at 8.0

the reaction mixture revealed the water peak at $2.45 \mathrm{ppm}$. This is significantly shifted from where water in pure $\mathrm{C}_{6} \mathrm{D}_{6}$ appears $(0.5 \mathrm{ppm})$. The change in the chemical shift of the water is presumably due to hydrogen bonding between the water and the phosphoryl oxygen of dppePdPh $\left(\mathrm{P}(\mathrm{O})(\mathrm{OEt})_{2}\right)$. Consistent with this observation is the presence of 1 equiv of water per $\mathrm{Pd}$ complex in virtually all of the crystallized compounds. In all of the crystalline samples, the water is hydrogen bonded to the phosphoryl oxygen. It should be pointed out that although the compounds are isolated as anhydrous materials, they are quite hygroscopic and will absorb water upon exposure to the atmosphere. To further probe the tolerance/ intolerance of the system to the presence of water, analogous reactions were carried out in the presence of 10 equiv of water. Curiously, instead of accelerating the elimination reaction, the $t_{1 / 2}$ for the complex was significantly increased. Similar to the reactions using 1 equiv of water, the compound was stable to the added water and the product distribution remained the same ( $>95 \%$ conversion into $\left.\mathrm{PhP}(\mathrm{O})(\mathrm{OEt})_{2}\right)$. It is noteworthy to point out that free palladium was not observed in any of these transformations. Thus, while the reductive elimination was tolerant of small amounts of water, increasing the level of water contamination lead to decreased reaction rates, but no change in product distributions.

To probe the electronic effects of adding donating and withdrawing groups to the metal-bound aryl fragments on the rate of phosphorus carbon bond formation, elimination from discrete species of the type diphosphine $\mathrm{Pd}\left(\mathrm{C}_{6} \mathrm{H}_{4} \mathrm{R}\right)\left(\mathrm{P}(\mathrm{O})(\mathrm{OEt})_{2}\right.$ ( $\mathrm{R}=\mathrm{OMe}, \mathrm{Me}, \mathrm{CN}, \mathrm{NO}_{2}$ ) was investigated. The results of this investigation are presented in Table 7 . Using this data, several observations and conclusions can be made about the elimination process. First, electron-poor aryl groups exhibited slower rates of reductive elimination relative to electron-rich aryl groups. Using the dppePdPh $\left(\mathrm{P}(\mathrm{O})(\mathrm{OEt})_{2}\right)$ as a baseline, incorporating a 4-CN group cuts the rate of reductive elimination in half, while adding an electron-donating 4-OMe group significantly increases the rate. These observations are consistent with a mechanism involving intramolecular attack of the ipso carbon from the metal-bound aryl fragment on the phosphorus center to generate the new phosphorus carbon bond. The presence of electrondonating groups would accelerate this process, while electronwithdrawing groups would slow the bond-forming reaction. While this is an attractive explanation, our kinetic model cannot rule out the possibility of a concerted reductive elimination.

Changing the supporting ligand from dppe to other diphosphine ligands dramatically affected the rate of the phosphoruscarbon bond forming reaction. Using dppp as the ancillary ligand resulted in significant increases in the rates of all the elimination reactions. The complexes dpppPd $\left(4-\mathrm{C}_{6} \mathrm{H}_{5} \mathrm{R}\right) \mathrm{P}(\mathrm{O})(\mathrm{OEt})_{2}(\mathrm{R}=$ $\mathrm{Me}, \mathrm{OMe}$ ) eliminated so rapidly at room temperature that an accurate determination of the rates was not possible. Comparing the two diphosphines revealed that elimination from the dppp derivatives was always faster than the dppe analogues. The observed increase in the rate of the reductive elimination reaction upon increasing the bite angle of the diphosphine is consistent with other bond-forming reactions. Changing the diphosphine to dpephos (bite angle $=105^{\circ}$ ) resulted in rapid reductive elimination for all cases. The large bite angle of dpephos could promote the reductive elimination reaction from a fourcoordinate species, or dissociation of one end of the diphosphine could generate a three-coordinate intermediate that undergoes rapid reductive elimination. It should be pointed out that our kinetic model cannot distinguish between dissociation of one end of the diphosphine to generate a three-coordinate intermediate that rapidly undergoes reductive elimination followed by rapid addition of the dangling phosphine and simple elimination from a four-coordinate complex.

The electronic effect observed in these metal phosphonate systems stands in contrast to virtually all other carbon-heteroelement 
Table 3. Structure Information for Alkyl and Arylpalladium Phosphonate Complexes

\begin{tabular}{|c|c|c|c|c|}
\hline & dppePd $\left(4-\mathrm{C}_{6} \mathrm{H}_{4} \mathrm{CN}\right)\left(\mathrm{P}(\mathrm{O})(\mathrm{OEt})_{2}\right)$ & $\mathrm{bu}_{2} \operatorname{bipyPd}\left(4-\mathrm{C}_{6} \mathrm{H}_{4} \mathrm{NO}_{2}\right)\left(\mathrm{P}(\mathrm{O})(\mathrm{OEt})_{2}\right)$ & dppePdMe $\left(\mathrm{P}(\mathrm{O})(\mathrm{OEt})_{2}\right)$ & bu $_{2}$ bipyPdPh $\left(\mathrm{P}(\mathrm{O})(\mathrm{OEt})_{2}\right)$ \\
\hline formula & $\mathrm{C}_{37} \mathrm{H}_{38} \mathrm{NO}_{3} \mathrm{P}_{3} \mathrm{Pd} \cdot \mathrm{H}_{2} \mathrm{O}$ & $\mathrm{C}_{28} \mathrm{H}_{38} \mathrm{~N}_{3} \mathrm{O}_{5} \mathrm{PPd} \cdot \mathrm{H}_{2} \mathrm{O}$ & $\begin{array}{r}\mathrm{C}_{31} \mathrm{H}_{37} \mathrm{O}_{3} \mathrm{P}_{3} \mathrm{Pd} \cdot\left(0.5 \mathrm{H}_{2} \mathrm{O}\right) \cdot \\
(0.25 \mathrm{THF}) \cdot\left(0.25 \mathrm{C}_{5} \mathrm{H}_{12}\right)\end{array}$ & $\mathrm{C}_{28} \mathrm{H}_{39} \mathrm{~N}_{2} \mathrm{O}_{3} \mathrm{PPd} \cdot \mathrm{H}_{2} \mathrm{O}$ \\
\hline formula wt & 762.01 & 652.00 & 701.99 & 607.00 \\
\hline space group & $P 2_{1} 2_{1} 2_{1}$ & $P \overline{1}$ & $P 2_{1} / c$ & $P \overline{1}$ \\
\hline$a(\AA)$ & $18.1086(12)$ & $10.8000(7)$ & $12.2388(5)$ & $11.2013(4)$ \\
\hline$b(\AA)$ & $21.8118(15)$ & $12.5432(9)$ & $14.5238(6)$ & $11.6154(4)$ \\
\hline$c(\AA)$ & $27.2808(18)$ & $12.6532(9)$ & 37.2223 & $13.3073(5)$ \\
\hline$\gamma(\mathrm{deg})$ & 90 & $115.2270(10)$ & 90 & $103.874(1)$ \\
\hline temp $(\mathrm{K})$ & $100(2)$ & $100(2)$ & $100(2)$ & $100(2)$ \\
\hline$V\left(\AA^{3}\right)$ & $10775.4(13)$ & $1496.20(18)$ & $6536.1(5)$ & $1420.82(9)$ \\
\hline$Z$ & 12 & 2 & 8 & 2 \\
\hline$\theta_{\max }(\mathrm{deg})$ & 27.45 & 26.98 & 26.21 & 27.77 \\
\hline$d($ calcd $)\left(\mathrm{Mg} \mathrm{m}^{-3}\right)$ & 1.409 & 1.447 & 1.427 & 1.419 \\
\hline no. of rflns collected & 134068 & 18415 & 66097 & 17609 \\
\hline
\end{tabular}

Table 4. Selected Bond Distances ( $($ ) and Angles (deg) for $\mathrm{bu}_{2}$ bipyPd $\left(4-\mathrm{C}_{6} \mathrm{H}_{4} \mathrm{R}\right)\left(\mathrm{P}(\mathrm{O})(\mathrm{OEt})_{2}\right.$ Complexes

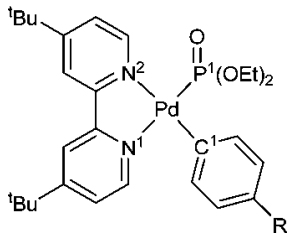

\begin{tabular}{lcc}
\hline & $\mathrm{R}=\mathrm{H}$ & $\mathrm{R}=\mathrm{NO}_{2}$ \\
\hline $\mathrm{Pd}(1)-\mathrm{C}(1)$ & $1.9965(13)$ & $1.994(2)$ \\
$\mathrm{Pd}(1)-\mathrm{N}(1)$ & $2.1336(11)$ & $2.1274(17)$ \\
$\mathrm{Pd}(1)-\mathrm{N}(2)$ & $2.1349(11)$ & $2.1254(16)$ \\
$\mathrm{Pd}(1)-\mathrm{P}(1)$ & $2.2266(3)$ & $2.2381(5)$ \\
$\mathrm{P}(1)-\mathrm{O}(1)$ & $1.4988(10)$ & $1.4979(14)$ \\
$\mathrm{N}(2)-\mathrm{Pd}-\mathrm{P}(1)$ & $98.82(3)$ & $107.53(5)$ \\
$\mathrm{N}(2)-\mathrm{Pd}-\mathrm{N}(1)$ & $76.97(4)$ & $76.81(6)$ \\
$\mathrm{N}(1)-\mathrm{Pd}-\mathrm{C}(1)$ & $93.89(5)$ & $94.17(7)$ \\
$\mathrm{C}(1)-\mathrm{P}(1)$ & $90.47(4)$ & $81.32(6)$ \\
$\mathrm{C}(1)-\mathrm{N}(2)$ & $170.57(5)$ & $169.81(17)$ \\
$\mathrm{N}(1)-\mathrm{Pd}-\mathrm{P}(1)$ & $173.98(3)$ & $175.15(5)$
\end{tabular}

Table 5. Selected Bond Distances $(\AA)$ and Angles (deg) for $\operatorname{dppePd}(\mathbf{R})\left(\mathbf{P}(\mathrm{O})(\mathrm{OEt})_{2}\right.$ Complexes

\begin{tabular}{lcc} 
& \\
& & \\
& $\mathrm{C}=\mathrm{Me}$ & $\mathrm{C}=4-\mathrm{C}_{6} \mathrm{H}_{4} \mathrm{CN}$ \\
\hline $\mathrm{Pd}(1)-\mathrm{C}(1)$ & $2.101(3)$ & $2.065(2)$ \\
$\mathrm{Pd}(1)-\mathrm{P}(1)$ & $2.3325(7)$ & $2.3575(5)$ \\
$\mathrm{Pd}(1)-\mathrm{P}(2)$ & $2.3215(7)$ & $2.3203(6)$ \\
$\mathrm{Pd}(1)-\mathrm{P}(3)$ & $2.2941(8)$ & $2.2962(6)$ \\
$\mathrm{P}(3)-\mathrm{O}(1)$ & $1.500(3)$ & $1.4961(17)$ \\
$\mathrm{P}(1)-\mathrm{Pd}-\mathrm{P}(3)$ & $100.88(3)$ & $99.37(2)$ \\
$\mathrm{P}(2)-\mathrm{Pd}-\mathrm{P}(1)$ & $84.35(3)$ & $84.73(2)$ \\
$\mathrm{P}(2)-\mathrm{Pd}-\mathrm{C}(1)$ & $90.06(9)$ & $91.33(6)$ \\
$\mathrm{C}(1)-\mathrm{Pd}-\mathrm{P}(3)$ & $84.51(9)$ & $84.70(6)$ \\
$\mathrm{C}(1)-\mathrm{Pd}-\mathrm{P}(1)$ & $174.32(9)$ & $175.91(6)$ \\
$\mathrm{P}(2)-\mathrm{Pd}-\mathrm{P}(3)$ & $169.82(3)$ & $168.63(2)$
\end{tabular}

bond forming reactions that have been reported from $\mathrm{Pd}(\mathrm{II}){ }^{40,46}$ Elegant work by Hartwig and others has shown that reductive elimination from arylpalladium alkoxides, ${ }^{47,48}$ sulfides, ${ }^{49}$ and

(46) Hartwig, J. F. Acc. Chem. Res. 1998, 31, 852.

(47) Mann, G.; Shelby, Q.; Roy, A. H.; Hartwig, J. F. Organometallics 2003, 22, 2775.
Table 6. Effect of Additives of Elimination Reaction ${ }^{a}$

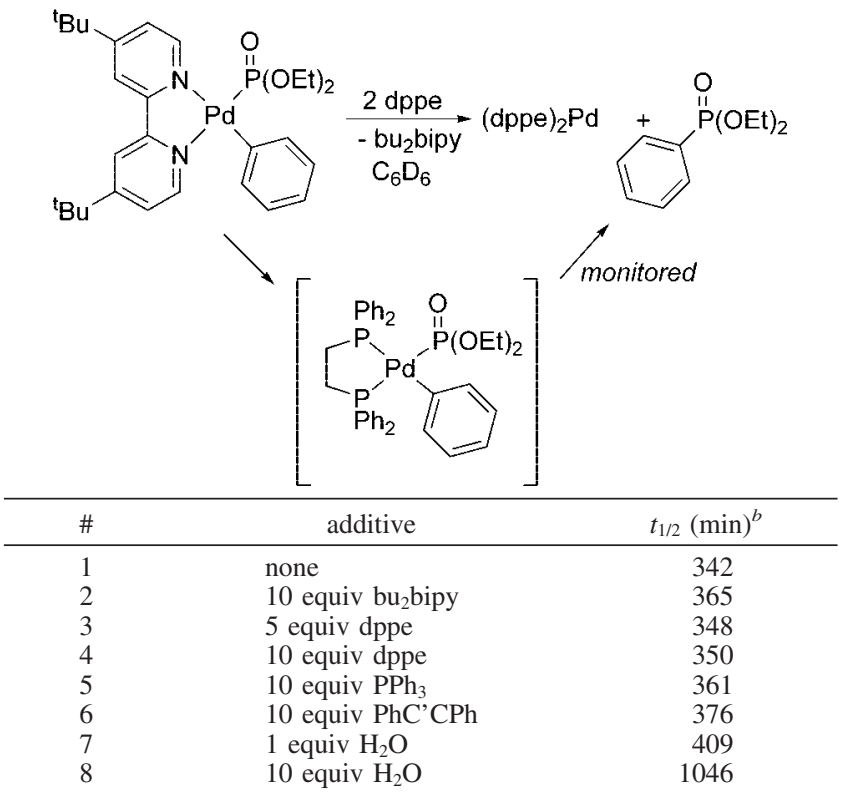

${ }^{a}$ Reactions carried out in $\mathrm{C}_{6} \mathrm{D}_{6}$ at $22{ }^{\circ} \mathrm{C} .{ }^{b}$ The half-life is the time required for $1 / 2$ of the complex to be consumed and is reported as the average of duplicate experiments.

amides $^{50}$ containing Pd(II) complexes was accelerated by the presence of electron-withdrawing groups on the metal-bound aryl fragment. Although the obvious difference between the phosphonate systems presented in this work and the elimination studies involving $-\mathrm{OR},-\mathrm{NR}_{2}$, and $-\mathrm{PR}_{2}$ is the absence of the lone pair on the heteroatom, recent studies have suggested that the electronic effects observed in carbon-heteroelement bond forming reactions are the result of perturbations of the $\sigma$-network and that $\pi$-contributions are minimal. ${ }^{40}$ It should also be noted that the rate of reductive elimination of an arylphosphine from a diphosphine-ligated palladium phosphide was accelerated upon incorporation of an electron-withdrawing group $\left(-\mathrm{NO}_{2}\right)$ into the metal-bound aryl group. ${ }^{12 \mathrm{e}}$ The Hammett analysis of the rates of elimination relative to the complex containing the

(48) Widenhoefer, R. A.; Zhong, H. A.; Buchwald, S. L. J. Am. Chem. Soc. 1997, 119, 6787.

(49) Mann, G.; Baranano, D.; Hartwig, J. F.; Rheingold, A. L.; Guzei, I. A. J. Am. Chem. Soc. 1998, 120, 9205.

(50) Driver, M. S.; Hartwig, J. F. J. Am. Chem. Soc. 1997, 119, 8232. 
Table 7. Electronic and Steric Effect on Alkyl and Arylphosphonate Elimination from Model Compounds ${ }^{a}$

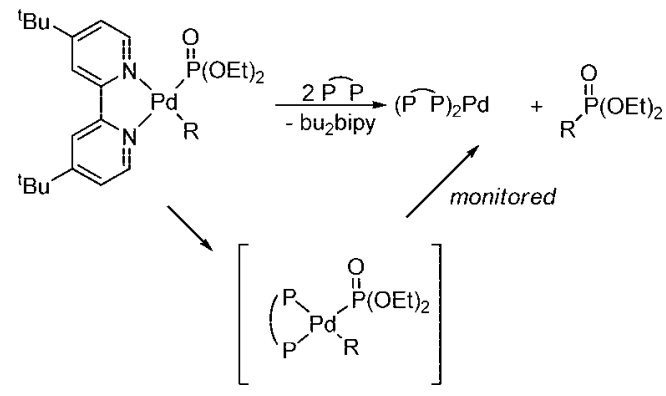

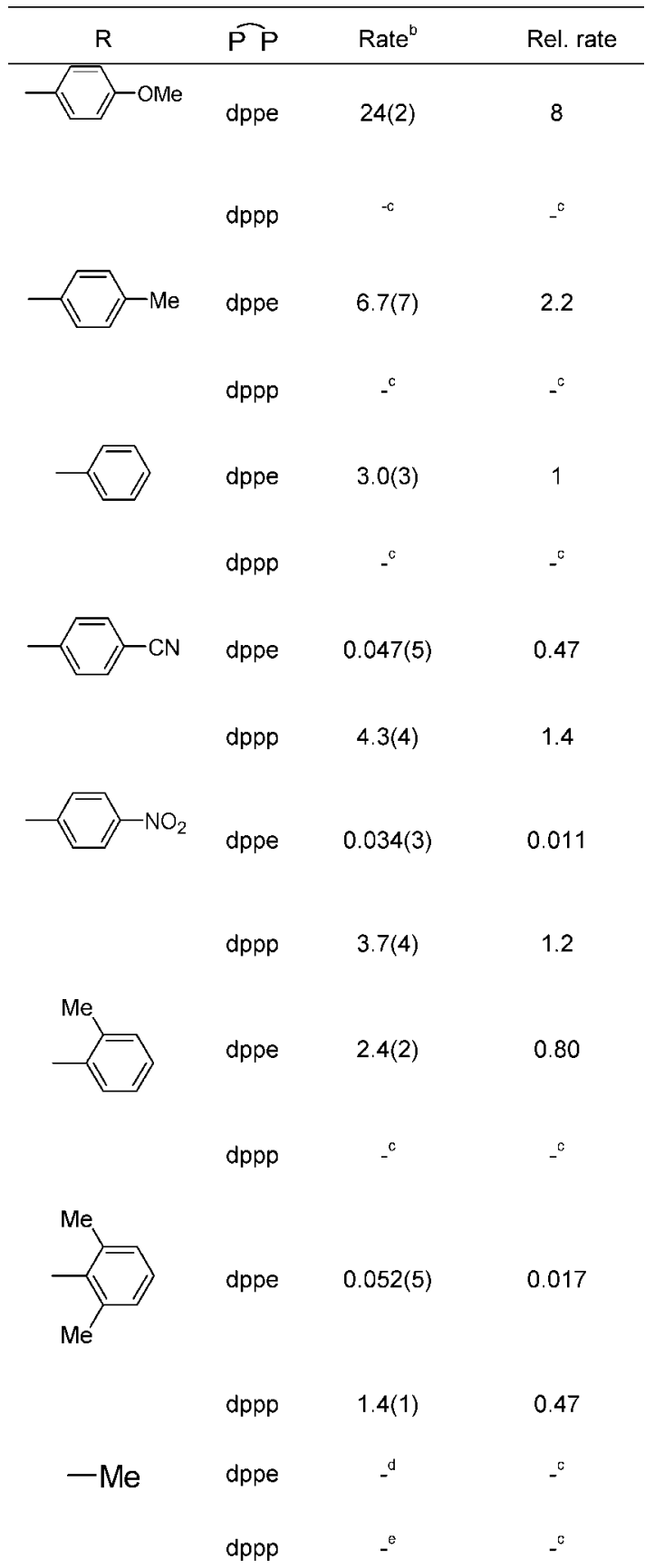

${ }^{a}$ Reactions carried out in $\mathrm{C}_{6} \mathrm{D}_{6}$ at $22{ }^{\circ} \mathrm{C} .{ }^{b}$ Rates $\left(k_{\mathrm{obs}}\right)$ are reported in $\mathrm{s}^{-1}(\times 100000)$ and are $\pm 10 \%$. ${ }^{c}$ The elimination was too fast for accurate rate determination. ${ }^{d}$ Less than $1 \%$ elimination was observed after standing at $22{ }^{\circ} \mathrm{C}$ for $43200 \mathrm{~min} .5 \%$ elimination product was observed after standing at $22{ }^{\circ} \mathrm{C}$ for $45120 \mathrm{~min}$. The relative rate is by comparison to the electron neutral phenyl derivative.

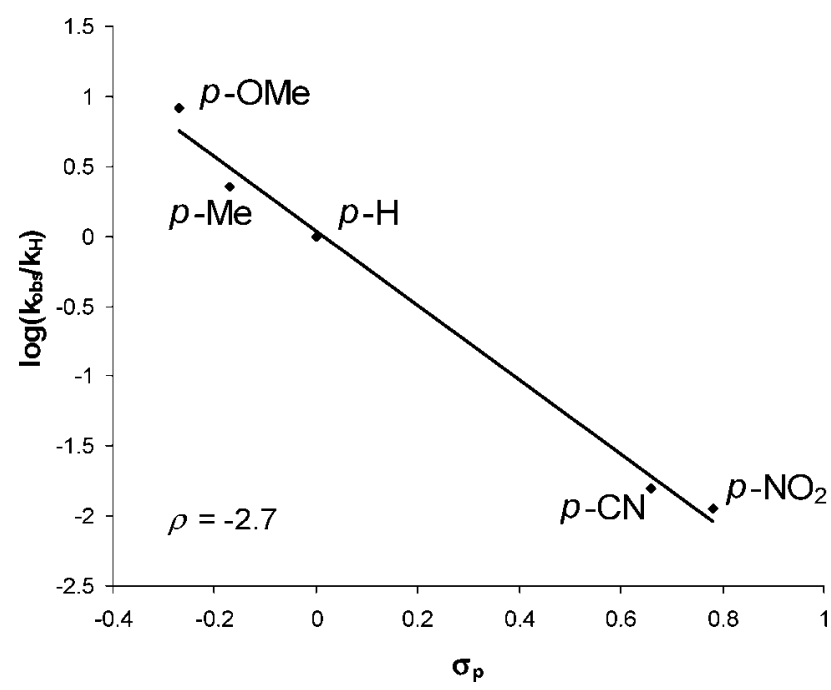

Figure 2. Hammett analysis for elimination from dppePd(4$\left.\mathrm{C}_{6} \mathrm{H}_{4} \mathrm{X}\right)\left(\mathrm{P}(\mathrm{O})(\mathrm{OEt})_{2}\right)$ species.

electron-neutral phenyl group is shown in Figure 2. A nearly linear relationship between $\sigma_{\mathrm{p}}$ and the rate of elimination was obtained ( $\left.\rho_{\mathrm{I}}=-2.7 ; R^{2}=0.99\right)$. Comparisons between these $\rho_{\mathrm{I}}$ values and other carbon-heteroelement bond forming reactions would be of interest; however, the inductive $\sigma$ parameter provided poor correlations for elimination of aryl sulfides and aryl amines. ${ }^{40,46,50}$ Linear correlations were observed using a parameter that accounted for the resonance effects of the substituents $\left(\sigma_{\mathrm{R}}\right)$. The $\rho_{\mathrm{I}}$ value for carbon-carbon bond forming reactions from $\mathrm{Pd}(\mathrm{II})$ would also be a useful comparison for this chemistry; however, the formation of biaryls from palladium(II) is often too rapid for accurate measurement. The formation of biaryls by reductive elimination from diarylplatinum complexes of the type (DPPF) $\mathrm{Pt}\left(\mathrm{C}_{6} \mathrm{H}_{4} \mathrm{R}\right)_{2}$ and (DPPF)$\mathrm{Pt}\left(\mathrm{C}_{6} \mathrm{H}_{4} \mathrm{CF}_{3}\right)\left(\mathrm{C}_{6} \mathrm{H}_{4} \mathrm{R}\right)$ has been studied, and $\rho_{\mathrm{I}}$ values of -0.9 and -1.5 have been determined. ${ }^{51}$

The steric effect of the metal-bound aryl group was investigated by adding one or two methyl groups to the ortho positions of the metal-bound aryl fragment. Adding a single methyl group resulted in an elimination rate that was roughly equivalent to having a phenyl group attached to the metal. However, incorporating two methyl groups drastically reduced the rate of the reaction. This is consistent with $\pi$-type coordination of the eliminated arylphosphonate species to the palladium complex. ${ }^{49}$ Only having one group does not strongly inhibit this coordination; however, two ortho substituents significantly affects the coordination and slows the reaction. The sluggish rate could also be due to the bulky groups hindering close approach of phosphorus and carbon.

A comparison of the electronic and steric properties of the metal-bound aryl group revealed that changing the identity of the diphosphine reversed the importance of these properties. Comparing the rates of elimination for dppePdR $\left(\mathrm{P}(\mathrm{O})(\mathrm{OEt})_{2}\right)$ complexes bearing 2,6- $\mathrm{C}_{6} \mathrm{H}_{3} \mathrm{Me}_{2}$ group and a $4-\mathrm{C}_{6} \mathrm{H}_{4} \mathrm{CN}$ group revealed that the electronic component is more important for the rate of elimination in these species, and slower rates of elimination were observed for the sterically hindered species. Curiously, increasing the chain length of the diphosphine ligand reverses this observation. For example, the steric component overpowers the electronic and the rate of elimination for dpppPd $\left(4-\mathrm{C}_{6} \mathrm{H}_{4} \mathrm{CN}\right)\left(\mathrm{P}(\mathrm{O})(\mathrm{OEt})_{2}\right)$ is faster than from dpppPd(2,6$\left.\mathrm{C}_{6} \mathrm{H}_{3} \mathrm{Me}_{2}\right)\left(\mathrm{P}(\mathrm{O})(\mathrm{OEt})_{2}\right)$.

(51) Shekhar, S.; Hartwig, J. F. J. Am. Chem. Soc. 2004, 126, 13016. 
Table 8. Summary of Calculated Gas Phase Kinetic Data

\begin{tabular}{|c|c|c|c|}
\hline substituent & $\sigma_{\mathrm{p}}$ & $k(1 / \mathrm{s})$ & $\log \left(k / k_{\mathrm{H}}\right)$ \\
\hline $\mathrm{NMe}_{2}$ & -0.83 & $1.99 \times 10^{4}$ & 1.42 \\
\hline $\mathrm{NH}_{2}$ & -0.66 & $9.96 \times 10^{3}$ & 1.12 \\
\hline $\mathrm{OMe}$ & -0.27 & $5.57 \times 10^{3}$ & 0.87 \\
\hline $\mathrm{Me}$ & -0.17 & $6.05 \times 10^{2}$ & -0.10 \\
\hline $\mathrm{H}$ & 0 & $7.54 \times 10^{2}$ & 0 \\
\hline $\mathrm{C}_{2} \mathrm{H}$ & 0.23 & $1.76 \times 10^{2}$ & -0.63 \\
\hline $\mathrm{CHO}$ & 0.42 & $6.56 \times 10$ & -1.06 \\
\hline $\mathrm{CF}_{3}$ & 0.54 & 6.64 & -2.05 \\
\hline $\mathrm{CN}$ & 0.66 & $3.95 \times 10$ & -1.28 \\
\hline $\mathrm{NO}_{2}$ & 0.78 & $2.82 \times 10$ & -1.43 \\
\hline
\end{tabular}

Table 9. Summary of Calculated Solvent Phase Kinetic Data

\begin{tabular}{|c|c|c|c|}
\hline substituent & $\sigma_{\mathrm{p}}$ & $k(\operatorname{solv}, 1 / \mathrm{s})$ & $\log \left(\mathrm{k} / \mathrm{k}_{\mathrm{h}}\right)$ (solv) \\
\hline $\mathrm{NMe}_{2}$ & -0.83 & $3.85 \times 10^{4}$ & 1.94 \\
\hline $\mathrm{NH}_{2}$ & -0.66 & $8.50 \times 10^{3}$ & 1.29 \\
\hline $\mathrm{OMe}$ & -0.27 & $5.06 \times 10^{3}$ & 1.06 \\
\hline $\mathrm{Me}$ & -0.17 & $2.99 \times 10^{2}$ & -0.17 \\
\hline $\mathrm{H}$ & 0 & $4.40 \times 10^{2}$ & 0 \\
\hline $\mathrm{C}_{2} \mathrm{H}$ & 0.23 & $1.43 \times 10^{2}$ & -0.49 \\
\hline $\mathrm{CHO}$ & 0.42 & $2.67 \times 10$ & -1.22 \\
\hline $\mathrm{CF}_{3}$ & 0.54 & 3.40 & -2.11 \\
\hline $\mathrm{CN}$ & 0.66 & $1.12 \times 10$ & -1.59 \\
\hline $\mathrm{NO}_{2}$ & 0.78 & 7.55 & -1.77 \\
\hline
\end{tabular}

Computational Investigation of the Reductive Elimination Reaction. A Hammett analysis utilizing density functional theory was carried out using the substituents and associated kinetic data listed in Table 8 (gas phase simulations) and Table 9 (simulations in benzene solvent) and plotted in Figures 3 and 4. For this computational analysis, a reductive elimination mechanism was assumed for the $\mathrm{P}-\mathrm{C}$ bond forming reaction. Both the gas phase and solvated (benzene) values produce a negative $\rho_{\mathrm{I}}$ of moderate magnitude $(-2.0$ (gas phase) or -2.4 (benzene)). Electron-withdrawing groups in the para position retard the reaction, so it is assumed that the $\mathrm{Pd}-\mathrm{C}($ ipso $)$ bond donates electrons to the $\mathrm{Pd}$ center in the reductive elimination. These DFT results, which are consistent in both magnitude and direction with the experimental Hammett analysis (vide supra), support the contention that the mechanism of $\mathrm{P}-\mathrm{C}$ bond formation is a reductive elimination for which electron-releasing substituents accelerate the process. Furthermore, the small difference between the benzene and gas phase calculated $\rho_{\mathrm{I}}$ argues against mechanisms in which there is significant charge buildup in the transition state.

\section{Summary}

A series of arylpalladium phosphonate complexes have been prepared, characterized, and studied as key intermediates in palladium-catalyzed coupling reactions. All of the palladium complexes eliminated the arylphosphonate species in high yields under mild conditions. In contrast to virtually all other carbon-heteroatom bond forming reactions from palladium(II), the presence of electron-withdrawing groups on the metal-bound aryl group induced slower rates of reductive elimination. The Hammett analysis revealed a linear dependence on sigma with a $\rho_{\mathrm{I}}=-2.7$. A computational study corroborated this experimental investigation and also found a linear dependence on $\sigma_{\mathrm{p}}$ with $\rho=-2.4$ for the solvated (benzene) model system.

\section{Experimental Section}

General Considerations. Diethyl ether, dichloromethane, and hexane were dried using a Grubbs-style solvent purification system. $\mathrm{C}_{6} \mathrm{D}_{6}$ and tol- $d_{8}$ were dried over molecular sieves. The diphosphine ligands, (methoxymethyl)diphenylphosphine oxide, and $b_{2}$ bipy were obtained from Aldrich and used as received. The bu ${ }_{2}$ bipyPd$(\mathrm{Ar})\left(\mathrm{P}(\mathrm{O})(\mathrm{OEt})_{2}\right)$ precursors were prepared following literature

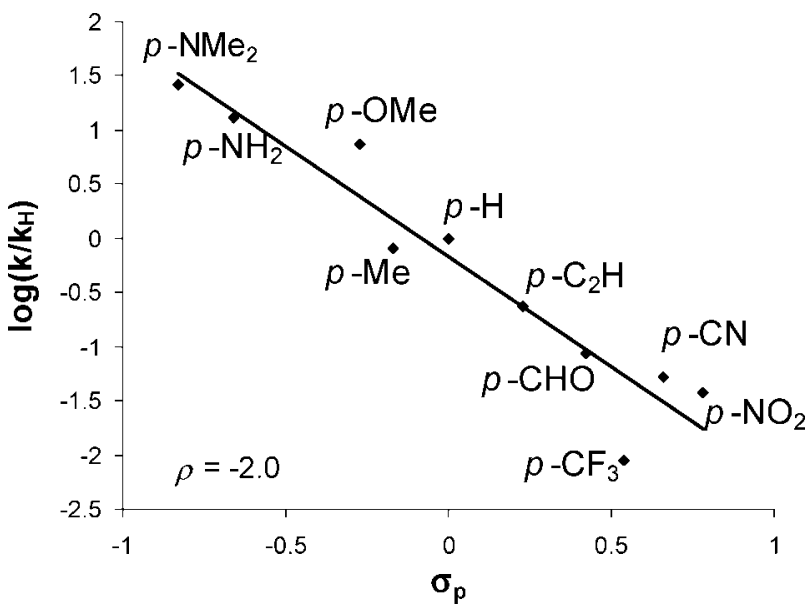

Figure 3. Hammett plot for phosphorus-carbon bond forming reaction (gas phase).

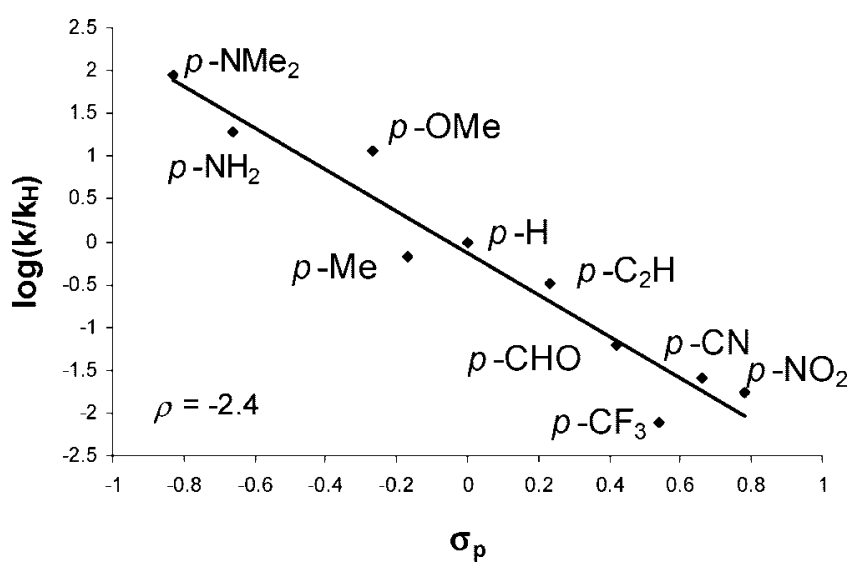

Figure 4. Hammett plot for phosphorus-carbon bond forming reaction (solvated: benzene).

procedures. ${ }^{11 a}$ All yields are based upon isolated material unless specified. ${ }^{1} \mathrm{H}$ and ${ }^{13} \mathrm{C}$ chemical shifts were determined by reference to residual protonated solvent resonances or $\mathrm{Me}_{4} \mathrm{Si}$. All coupling constants are given in hertz. ${ }^{31} \mathrm{P}\left\{{ }^{1} \mathrm{H}\right\}$ NMR spectra were referenced to external $\mathrm{H}_{3} \mathrm{PO}_{4}(0 \mathrm{ppm})$. Integratable ${ }^{31} \mathrm{P}\left\{{ }^{1} \mathrm{H}\right\}$ NMR spectra were recorded using an inverse-gated decoupling sequence (decoupling only during acquisition) using a $30 \mathrm{~s}$ recycle delay. Arylphosphonates were identified by comparison of the spectroscopic data to authentic samples or literature values. ${ }^{2,11 a, 52,53}$

Preparation of bu $\mathbf{b u}_{2}$ bipyPd(Me)(P(O)(OEt $\left.)_{2}\right)$. A $100 \mathrm{~mL}$ roundbottom flask was charged with bu ${ }_{2}$ bipyPdMeCl $(0.100 \mathrm{~g}, 0.235$ $\mathrm{mmol}), \operatorname{Ag}\left[\mathrm{P}(\mathrm{O})(\mathrm{OEt})_{2}\right](0.058 \mathrm{~g}, 0.236 \mathrm{mmol})$, and a magnetic stirring bar. The flask was capped, evacuated, and filled with nitrogen. Dichloromethane $(50 \mathrm{~mL})$ was added by syringe, and the reaction mixture was stirred for $2 \mathrm{~h}$ in the dark. The reaction mixture was passed through a short plug of Celite followed by removal of the volatiles to afford the title compound $(0.11 \mathrm{~g}, 88.7 \%)$ as a white solid. Anal. Calcd for $\mathrm{C}_{23} \mathrm{H}_{37} \mathrm{~N}_{2} \mathrm{O}_{3}$ PPd: C, 52.42; H, 7.08. Found: $\mathrm{C}, 52.34 ; \mathrm{H}, 7.01 .{ }^{1} \mathrm{H}$ NMR $\left(\mathrm{CDCl}_{3}, 25{ }^{\circ} \mathrm{C}\right): \delta 10.11(\mathrm{~d}, 1 \mathrm{H}, J=$ 6.0, Ar-H), 8.59 (dd, $1 \mathrm{H}, J=5.8,3.3, \mathrm{Ar}-\mathrm{H}), 8.01$ (s, $1 \mathrm{H}, \mathrm{Ar}-\mathrm{H})$, $7.94(\mathrm{~s}, 1 \mathrm{H}, \mathrm{Ar}-\mathrm{H}), 7.51(\mathrm{~m}, 2 \mathrm{H}, \mathrm{Ar}-\mathrm{H}), 4.08\left(\mathrm{~m}, 4 \mathrm{H},-\mathrm{OCH}_{2} \mathrm{CH}_{3}\right)$, 1.44 (s, 9H, $-\mathrm{CMe}_{3}$ ), 1.41 (s, 9H, $-\mathrm{CMe}_{3}$ ), 1.31 (t, $6 \mathrm{H}, J=7.0$, $\left.-\mathrm{OCH}_{2} \mathrm{C} H_{3}\right), 0.79(\mathrm{~d}, 3 \mathrm{H}, J=0.8, \mathrm{PdMe}) .{ }^{13} \mathrm{C}\left\{{ }^{1} \mathrm{H}\right\} \mathrm{NMR}\left(\mathrm{CDCl}_{3}\right.$, $25^{\circ} \mathrm{C}$ ): $\delta 163.7$ (s, quat), 162.4 (s, quat), 156.1 (d, $J=1.7$, quat), $153.8(\mathrm{~d}, J=1.5$, quat), $153.6(\mathrm{~s}, \mathrm{Ar}-\mathrm{H}), 147.2(\mathrm{~s}, \mathrm{Ar}-\mathrm{H}), 123.6$

(52) Kagayama, T.; Nakano, A.; Sakaguchi, S.; Ishii, Y. Org. Lett. 2006, $8,407$.

(53) Kottmann, H.; Skarzewski, J.; Effenberger, F. Synthesis 1987, 797. 
(s, Ar-H), 122.8 (d, $J=2.9$, Ar-H), 118.0 (d, $J=3.0$, Ar-H), 117.5 (s, Ar-H), 57.7 (d, $\left.J=2.9,-\mathrm{OCH}_{2} \mathrm{CH}_{3}\right), 35.4$ (s, $\left.-\mathrm{CMe}_{3}\right), 35.2$ (s, $\left.-\mathrm{CMe}_{3}\right), 30.34\left(\mathrm{~s},-\mathrm{CMe}_{3}\right), 30.31\left(\mathrm{~s},-\mathrm{CMe}_{3}\right), 16.8$ (d, $J=$ $\left.7.5,-\mathrm{OCH}_{2} \mathrm{CH}_{3}\right),-1.9(\mathrm{~d}, J=5.2,-\mathrm{Pd} M e) .{ }^{31} \mathrm{P}\left\{{ }^{1} \mathrm{H}\right\} \quad \mathrm{NMR}$ $\left(\mathrm{CDCl}_{3}, 25^{\circ} \mathrm{C}\right): \delta 72.6$.

General Procedure for Isolation of DiphosphinePd $(R)(P(O)-$ $\left.(\mathbf{O E t})_{2}\right)$ Species. A $10 \mathrm{~mL}$ reaction vial was charged with the appropriate bu $_{2}$ bipyPd $(\mathrm{R})\left(\mathrm{P}(\mathrm{O})(\mathrm{OEt})_{2}\right)$ precursor and 1 equiv of the diphosphine. After evacuating and refilling with nitrogen, anhydrous ether $(5 \mathrm{~mL})$ was injected by syringe. After stirring for $3 \mathrm{~h}$, the solid was separated using a centrifuge, and the resulting solid was washed with diethyl ether $(2 \times 3 \mathrm{~mL})$ and dried under vacuum. ${ }^{31} \mathrm{P}\left\{{ }^{1} \mathrm{H}\right\}$ NMR spectroscopic data for the isolated and observed compounds are summarized in Table 2.

Preparation of dppePd $\left(4-\mathrm{C}_{6} \mathrm{H}_{4} \mathrm{CN}\right)\left(\mathrm{P}(\mathrm{O})(\mathrm{OEt})_{2}\right)$. The general procedure was followed using bu $\mathrm{b}_{2}$ bipyPd $\left(4-\mathrm{C}_{6} \mathrm{H}_{4} \mathrm{CN}\right)\left(\mathrm{P}(\mathrm{O})(\mathrm{OEt})_{2}\right)$ $(0.020 \mathrm{~g}, 0.033 \mathrm{mmol})$ and dppe $(0.013 \mathrm{~g}, 0.033 \mathrm{mmol})$ to afford $0.018 \mathrm{~g}(75 \%)$ as a white solid. Anal. Calcd for $\mathrm{C}_{37} \mathrm{H}_{38} \mathrm{NO}_{3} \mathrm{P}_{3} \mathrm{Pd}$ : C, 59.73; H, 5.15. Found: C, 60.05; H, 4.85. ${ }^{1} \mathrm{H}$ NMR $\left(\mathrm{C}_{6} \mathrm{D}_{6}, 25\right.$ $\left.{ }^{\circ} \mathrm{C}\right): \delta 7.93(\mathrm{~m}, 4 \mathrm{H}, \mathrm{Ar}-\mathrm{H}), 7.62(\mathrm{~m}, 2 \mathrm{H}, \mathrm{Ar}-\mathrm{H}), 6.88-7.18(\mathrm{~m}$, $18 \mathrm{H}, \mathrm{Ar}-\mathrm{H}), 3.88\left(\mathrm{~m}, 2 \mathrm{H},-\mathrm{OCH}_{2} \mathrm{CH}_{3}\right), 3.61\left(\mathrm{~m}, 2 \mathrm{H},-\mathrm{OCH}_{2} \mathrm{CH}_{3}\right)$, $1.72\left(\mathrm{~m}, 4 \mathrm{H},-\mathrm{PCH}_{2} \mathrm{CH}_{2} \mathrm{P}-\right), 0.80\left(\mathrm{t}, 6 \mathrm{H}, \mathrm{J}=7.2,-\mathrm{OCH}_{2} \mathrm{CH}_{3}\right)$.

Preparation of dppePd $\left(4-\mathrm{C}_{6} \mathrm{H}_{4} \mathrm{NO}_{2}\right)\left(\mathrm{P}(\mathrm{O})(\mathrm{OEt})_{2}\right)$. The general procedure was followed using bu ${ }_{2}$ bipyPd $\left(4-\mathrm{C}_{6} \mathrm{H}_{4} \mathrm{NO}_{2}\right)(\mathrm{P}(\mathrm{O})-$ $\left.(\mathrm{OEt})_{2}\right)(0.020 \mathrm{~g}, 0.032 \mathrm{mmol})$ and dppe $(0.013 \mathrm{~g}, 0.032 \mathrm{mmol})$ to afford $0.015 \mathrm{~g}(63 \%)$ as a white solid. Anal. Calcd for $\mathrm{C}_{36} \mathrm{H}_{38} \mathrm{NO}_{5} \mathrm{P}_{3} \mathrm{Pd}: \mathrm{C}, 56.59 ; \mathrm{H}, 5.01$. Found: C, 56.88; H, 4.22. ${ }^{1} \mathrm{H}$ NMR $\left(\mathrm{C}_{6} \mathrm{D}_{6}, 25{ }^{\circ} \mathrm{C}\right): \delta 7.92(\mathrm{~m}, 4 \mathrm{H}, \mathrm{Ar}-\mathrm{H}), 7.61(\mathrm{~m}, 2 \mathrm{H}, \mathrm{Ar}-\mathrm{H})$, 6.90-7.14 (m, 18H, Ar-H), $3.65\left(\mathrm{~m}, 2 \mathrm{H},-\mathrm{OCH}_{2} \mathrm{CH}_{3}\right), 3.61(\mathrm{~m}$, $\left.2 \mathrm{H},-\mathrm{OCH}_{2} \mathrm{CH}_{3}\right), 1.68\left(\mathrm{~m}, 4 \mathrm{H},-\mathrm{PCH}_{2} \mathrm{CH}_{2} \mathrm{P}-\right), 0.83(\mathrm{t}, 6 \mathrm{H}, J=$ 7.2, $-\mathrm{OCH}_{2} \mathrm{CH}_{3}$ ).

Preparation of dppePd $\left(2-\mathrm{C}_{6} \mathrm{H}_{4} \mathrm{Me}\right)\left(\mathrm{P}(\mathrm{O})(\mathrm{OEt})_{2}\right)$. The general procedure was followed using bu $\mathrm{bu}_{2}$ bipy $\mathrm{Pd}\left(2-\mathrm{C}_{6} \mathrm{H}_{4} \mathrm{Me}\right)\left(\mathrm{P}(\mathrm{O})(\mathrm{OEt})_{2}\right)$ $(0.020 \mathrm{~g}, 0.033 \mathrm{mmol})$ and dppe $(0.013 \mathrm{~g}, 0.033 \mathrm{mmol})$ to afford $0.010 \mathrm{~g}(42 \%)$ as a white solid. Anal. Calcd for $\mathrm{C}_{37} \mathrm{H}_{41} \mathrm{O}_{3} \mathrm{P}_{3} \mathrm{Pd}$ : C, 60.62; H, 5.64. Found: $\mathrm{C}, 60.69 ; \mathrm{H}, 5.31 .{ }^{1} \mathrm{H}$ NMR $\left(\mathrm{C}_{6} \mathrm{D}_{6}, 25{ }^{\circ} \mathrm{C}\right)$ : $\delta 8.10(\mathrm{~m}, 4 \mathrm{H}, \mathrm{Ar}-\mathrm{H}), 6.89-7.35(\mathrm{~m}, 20 \mathrm{H}, \mathrm{Ar}-\mathrm{H}), 3.70(\mathrm{~m}, 2 \mathrm{H}$, $\left.-\mathrm{OCH}_{2} \mathrm{CH}_{3}\right), 3.45\left(\mathrm{~m}, 2 \mathrm{H},-\mathrm{OCH}_{2} \mathrm{CH}_{3}\right), 2.50$ (s, $\left.3 \mathrm{H},-\mathrm{Me}\right), 1.80$ (m, $\left.4 \mathrm{H},-\mathrm{PCH}_{2} \mathrm{CH}_{2} \mathrm{P}-\right), 0.89$ (t, $\left.6 \mathrm{H},-\mathrm{OCH}_{2} \mathrm{CH}_{3}\right)$.

Preparation of dppePd $\left(\mathrm{C}_{6} \mathrm{H}_{5}\right)\left(\mathrm{P}(\mathrm{O})(\mathrm{OEt})_{2}\right)$. The general procedure was followed using bu bipyPd $_{2}\left(\mathrm{C}_{6} \mathrm{H}_{5}\right)\left(\mathrm{P}(\mathrm{O})(\mathrm{OEt})_{2}\right)(0.020$ $\mathrm{g}, 0.034 \mathrm{mmol})$ and dppe $(0.014 \mathrm{~g}, 0.034 \mathrm{mmol})$ to afford $0.015 \mathrm{~g}$ $(61 \%)$ as a white solid. Anal. Calcd for $\mathrm{C}_{36} \mathrm{H}_{39} \mathrm{O}_{3} \mathrm{P}_{3} \mathrm{Pd}$ : C, 60.13; $\mathrm{H}$, 5.47. Found: $\mathrm{C}, 60.27 ; \mathrm{H}, 5.30 .{ }^{1} \mathrm{H}$ NMR $\left(\mathrm{C}_{6} \mathrm{D}_{6}, 25^{\circ} \mathrm{C}\right): \delta 7.95$ (m, 4H, Ar-H), $7.75(\mathrm{~m}, 3 \mathrm{H}, \mathrm{Ar}-\mathrm{H}), 6.82-7.13(\mathrm{~m}, 18 \mathrm{H}, \mathrm{Ar}-\mathrm{H})$, $3.95\left(\mathrm{~m}, 2 \mathrm{H},-\mathrm{OCH}_{2} \mathrm{CH}_{3}\right), 3.62\left(\mathrm{~m}, 2 \mathrm{H},-\mathrm{OCH}_{2} \mathrm{CH}_{3}\right), 1.72(\mathrm{~m}$, $4 \mathrm{H},-\mathrm{PCH}_{2} \mathrm{CH}_{2} \mathrm{P}-$ ), 0.81 (t, $\left.6 \mathrm{H}, \mathrm{J}=7.4,-\mathrm{OCH}_{2} \mathrm{CH}_{3}\right)$.

Preparation of dppePd $\left(2,6-\mathrm{C}_{6} \mathrm{H}_{3} \mathrm{Me}_{2}\right)\left(\mathrm{P}(\mathrm{O})(\mathrm{OEt})_{2}\right)$. The general procedure was followed using bu bipyPd$_{2}\left(2,6-\mathrm{C}_{6} \mathrm{H}_{3} \mathrm{Me}_{2}\right)(\mathrm{P}(\mathrm{O})-$ $\left.(\mathrm{OEt})_{2}\right)(0.020 \mathrm{~g}, 0.032 \mathrm{mmol})$ and dppe $(0.013 \mathrm{~g}, 0.032 \mathrm{mmol})$ to afford $0.019 \mathrm{~g}(79 \%)$ as a white solid. Due to the slow rate of ligand displacement, this reaction was stirred for $24 \mathrm{~h}$ before isolation. Anal. Calcd for $\mathrm{C}_{38} \mathrm{H}_{43} \mathrm{O}_{3} \mathrm{P}_{3} \mathrm{Pd}$ : C, 61.09; $\mathrm{H}, 5.80$. Found: $\mathrm{C}, 61.36 ; \mathrm{H}, 6.37 .{ }^{1} \mathrm{H}$ NMR $\left(\mathrm{C}_{6} \mathrm{D}_{6}, 25^{\circ} \mathrm{C}\right): \delta 8.14(\mathrm{~m}, 4 \mathrm{H}, \mathrm{Ar}-\mathrm{H})$, 6.82-7.24 (m, 19H, Ar-H), $3.96\left(\mathrm{~m}, 2 \mathrm{H},-\mathrm{OCH}_{2} \mathrm{CH}_{3}\right), 3.60(\mathrm{~m}$, $\left.2 \mathrm{H},-\mathrm{OCH}_{2} \mathrm{CH}_{3}\right), 2.67$ (s, $\left.6 \mathrm{H},-\mathrm{Me}\right), 1.82\left(\mathrm{~m}, 4 \mathrm{H},-\mathrm{PCH}_{2} \mathrm{CH}_{2} \mathrm{P}-\right.$ ), 0.85 (t, 6H, $\left.-\mathrm{OCH}_{2} \mathrm{CH}_{3}\right)$.

Preparation of dppePd $(\mathrm{Me})\left(\mathrm{P}(\mathrm{O})(\mathrm{OEt})_{2}\right)$. The general procedure was followed using bu $\mathrm{bipyPd} \mathrm{Me})\left(\mathrm{P}(\mathrm{O})(\mathrm{OEt})_{2}\right)(0.020 \mathrm{~g}$, $0.038 \mathrm{mmol})$ and dppe $(0.015 \mathrm{~g}, 0.038 \mathrm{mmol})$ to afford $0.024 \mathrm{~g}$ (96\%) as a white solid. Anal. Calcd for $\mathrm{C}_{31} \mathrm{H}_{37} \mathrm{O}_{3} \mathrm{P}_{3} \mathrm{Pd}$ : C, 56.67; $\mathrm{H}$, 5.68. Found: $\mathrm{C}, 56.32 ; \mathrm{H}, 5.86 .{ }^{1} \mathrm{H}$ NMR $\left(\mathrm{C}_{6} \mathrm{D}_{6}, 25^{\circ} \mathrm{C}\right): \delta 7.91$ (m, 4H, Ar-H), 7.41 (m, 4H, Ar-H), 6.91-7.20 (m, 12H, Ar-H), $4.18\left(\mathrm{~m}, 4 \mathrm{H},-\mathrm{OCH}_{2} \mathrm{CH}_{3}\right), 1.80\left(\mathrm{~m}, 4 \mathrm{H},-\mathrm{PCH}_{2} \mathrm{CH}_{2} \mathrm{P}-\right), 1.42(\mathrm{~m}$, $3 \mathrm{H}, \mathrm{PdMe}), 1.08$ (t, 6H, $\left.-\mathrm{OCH}_{2} \mathrm{CH}_{3}\right)$.

Preparation of dpppPd(Me $)\left(\mathbf{P}(\mathrm{O})(\mathrm{OEt})_{2}\right)$. The general procedure was followed using bu ${ }_{2}$ bipyPd $(\mathrm{Me})\left(\mathrm{P}(\mathrm{O})(\mathrm{OEt})_{2}\right)(0.020 \mathrm{~g}$,
$0.038 \mathrm{mmol})$ and dppp (0.016 $\mathrm{g}, 0.038 \mathrm{mmol})$ to afford $0.012 \mathrm{~g}$ $(47 \%)$ as a white solid. Anal. Calcd for $\mathrm{C}_{32} \mathrm{H}_{39} \mathrm{O}_{3} \mathrm{P}_{3} \mathrm{Pd}$ : C, 57.28; $\mathrm{H}$, 5.86. Found: $\mathrm{C}, 56.97 ; \mathrm{H}, 5.49 .{ }^{1} \mathrm{H} \mathrm{NMR}\left(\mathrm{CDCl}_{3}, 25{ }^{\circ} \mathrm{C}\right): \delta$ 7.89 (m, 4H, Ar-H), 7.41 (m, 3H, Ar-H), 6.91-7.20 (m, 13H, Ar$\mathrm{H}), 4.18\left(\mathrm{~m}, 4 \mathrm{H},-\mathrm{OCH}_{2} \mathrm{CH}_{3}\right), 1.99\left(\mathrm{~m}, 2 \mathrm{H},-\mathrm{PCH}_{2} \mathrm{CH}_{2} \mathrm{C} \mathrm{H}_{2} \mathrm{P}-\right)$, $1.95\left(\mathrm{~m}, 4 \mathrm{H},-\mathrm{PCH}_{2} \mathrm{CH}_{2} \mathrm{CH}_{2} \mathrm{P}-\right)$, 1.37 (m, 3H, PdMe), 1.09 (t, $6 \mathrm{H},-\mathrm{OCH}_{2} \mathrm{CH}_{3}$ ).

General Procedure for Observation of DiphosphinePd$(\mathbf{R})\left(\mathbf{P}(\mathbf{O})(\mathbf{O E t})_{2}\right)$ Species. For compounds that underwent rapid reductive elimination, the following method was used for spectroscopic characterization at reduced temperatures. An oven-dried NMR tube was charged with bu $_{2}$ bipyPd( $(\mathrm{R})\left(\mathrm{P}(\mathrm{O})(\mathrm{OEt})_{2}\right), 1$ equiv of diphosphine, and $0.5 \mathrm{~mL}$ of $\mathrm{C}_{6} \mathrm{D}_{6}$. After shaking for 2 min the samples were placed into a cooled NMR spectrometer $\left(8^{\circ} \mathrm{C}\right)$ and ${ }^{1} \mathrm{H}$ and ${ }^{31} \mathrm{P}\left\{{ }^{1} \mathrm{H}\right\}$ NMR spectra were recorded.

Reductive Elimination of Arylphosphonates. Method A. An oven-dried NMR tube was charged with isolated diphosphineP$\mathrm{d}(\mathrm{R})\left(\mathrm{P}(\mathrm{O})(\mathrm{OEt})_{2}\right), 1$ equiv of diphosphine, (methoxymethyl)diphenylphosphine oxide (internal standard), and $0.5 \mathrm{~mL}$ of $\mathrm{C}_{6} \mathrm{D}_{6} \cdot{ }^{1} \mathrm{H}$ NMR spectra were collected over three half-lives. Comparison of the integral values of the palladium complex and arylphosphonate relative to the internal standard provided the concentrations of the complexes at specified times.

Method B. An oven-dried NMR tube was charged with $\mathrm{bu}_{2}$ bipyPd $(\mathrm{R})\left(\mathrm{P}(\mathrm{O})(\mathrm{OEt})_{2}\right), 2$ equiv of diphosphine, (methoxymethyl)diphenylphosphine oxide (internal standard), and $0.5 \mathrm{~mL}$ of $\mathrm{C}_{6} \mathrm{D}_{6}$. A ${ }^{1} \mathrm{H}$ NMR spectrum was recorded immediately to determine the extent of $\mathrm{bu}_{2}$ bipy displacement. Once the bipyridine ligand was fully displaced (within minutes in most cases), ${ }^{1} \mathrm{H}$ NMR spectra were systematically collected over three half-lives. Comparison of the integral values of the palladium complex and arylphosphonate relative to the internal standard provided the concentrations of the species.

Computational Studies. All calculations were performed with the Jaguar 5.5 code using the B3LYP/CSDZ* level of theory. Unless otherwise noted, stationary points have been confirmed by vibrational analysis using an analytic Hessian. Additionally, the transition mode for transition states has been visually inspected to correspond to the expected mode. All unimolecular rate constants were computed using RRKM theory at $300 \mathrm{~K}$. For reactions computed in solvent, the Poisson-Boltzmann equations were solved numerically using the parameters for benzene. In these cases, the barrier height was adjusted by adding the difference of the solvation corrections, retaining the same vibrational analysis of reactant and transition state for the prefactor computation. The diphosphine ligand is typically dppe in experimental systems, but the phenyls have been replaced with hydrogens for the sake of modeling simplicity.

Acknowledgment. The authors thank the National Science Foundation for the funds to purchase the NMR spectrometer (CHE-0521108) and acknowledge the U.S. Department of Education for their support of CASCaM. Calculations employed the UNT computational chemistry resource, the purchase of which was supported by a CRIF grant from the U.S. National Science Foundation (CHE-0342824). T.R.C. acknowledges NSF (CHE-0701247) for supporting his contribution. The authors thank Professor John Hartwig, Daniela Ide, and Marco Rodriguez-Lopez for helpful discussions.

Supporting Information Available: CIF files for the arylpalladium phosphonate complexes as well as details of the computational investigation are available free of charge via the Internet at http://pubs.acs.org.

OM800906M 